ACTA VET. BRNO, 56, 1987: 427-448

\title{
SYNDROME OF THE ASYMMETRY OF DIGITS AND THE FREQUENCY OF ITS OCCURRENCE IN SLAUGHTER PIGS
}

J. KAMAN, L. PIVNIK, I. HENYS, P. KAÑKA, V. VEVERKA

Department of Pathological Morphology and Parasitology, University of Veterinary Science, 61242 Brno

Received November 4, 1986

A b s t r act

Kaman J., L. Pivnik, I. Henyš, P. Kañka, $V$. $V$ e verka : Syndrome of the Asymmetry of Digits and the Frequency of its Occurrence in Slaughter Pigs. Acta Vet. Brno, 56, 1987: 427-

-448 .

The asymmetry of the digits was studied pathomorphologically and roentgenologically at the slaughtering line of a common slaughterhouse on hybrid sows and male castrates mostly of the Large white, Landrace and Belgian landrace breeds, their body mass being 90 - $110 \mathrm{~kg}$. The results demonstrated the consequences of this genetically conditioned anomaly also in slaughter pigs owing to pathomorphological changes and their functional and economic consequences. Various degrees of changes, affecting 1 - 4 limbs, were found in 797 ( 46.37 \%) out of 1702 investigated pigs; the incidence was almost equally frequent both in sows ( $47.48 \%$ ) and in tiogs $(46.17 \%)$.

In $26.63 \%$ of sows only one limb was found to be affected $(R T-3.77 \%, L T-4.02 \%, R P-8.54 \%, L P-10.30 \%)$; in $36.43 \%$ two limbs were affected $(T-5.53 \%, P-20.35 \%$, one thoracic and one pelvic limb independently on the side - $10.55 \%$; in $19.60 \%$ three limbs (two thoracic out of $3-6.53 \%$, two pelvic out of three - $13.07 \%$ ) and in $17.34 \%$ four limbs were affected (R - right, L - left, $T$ - thoracic, $P$ - pelvic).

In $22.54 \%$ of hogs only one limb was affected (RT - $5.70 \%$, $L T-5.18 \%, R P-5.18 \%, L P-6.48 \%)$; in $34.17 \%$ two limbs ( $T$ - $6.48 \%, P$ - $16.58 \%$, one thoracic and one pelvic independently of the side - $11.14 \%$ ); in $24.35 \%$ three limbs (out of these two thoracic - $7.77 \%$, two pelvic - $16.58 \%$ ) and in $18.91 \%$ four limbs were affected.

The asymmetry on the.pelvic limbs was found to be not only substantially more frequent but also more pronounced when compared with the thoracic limbs. Generally, its milder degree observed in slaughter pigs, compared with the breeding ones, was associated with a relatively lower age of the former. The lite- 
rature data concerning this topic are scarce and controversial. In this work the normal morphology of the pig autopodium is discussed from the viewpoint of objective evaluation of the digit asymmetry and the factors contributing to this different assessment.

The disproportion above all between the both chief digits, when digitus et metacarpus III are generally less developed, bear weight only partly or not at all and the weight takes over the digitus IV, with pathological consequences, is denoted as asymmetry.

Metapodium of the pig, digit asymmetry, motility disturbances, or thopedics, pathology, pig.

Among the defects of the locomotor apparatus of the pig, to which lately great attention is being paid, the disproportion in the development of digits with serious pathomorphological and pathophysiological consequences gains over increasing importance not only in breeding but also in market animals. The anomaly is visually striking by the smaller size of claws, being thus

not infrequently described as "disharmony of claws ( $L$ a b i $k$ et al. 1975; Labik, Pelikán 1975; Hovorka 1980b). This term was probably introduced by Nordby (1939).

The medial chief digit (digitus III) and the medial rudimental digit (digitus II) are shorter and their diameter is smaller than the analogical lateral digits (digitus IV et $V$ ), the medial claw and dew claw more narrow. Thus the larger proportion of the weight is supported by the outer claw which causes the overload thus inducing pathological changes, motility and posture disturbances.

All limbs can be affected, the affection of the pelvic limbs being more frequent and serious.

Nordby (1936) was the first to describe this anomaly in America. In his later work (Nordby 1939) the author came to the conclusion that the defect was inherited, not however determining the way of inheritance. Schumann (1957) in her study on inherited anomalies of the porcine limb concerned with the digit asymmetry published in the Tierärztliche Umschau presents only the findings of Nordby. In pigs in Norway the disproportion of digits was observed by $S k j e r v o l d$ (1966) and Amrud (1967). According to $L$ e m a $n$ et al. (1981) the lateral phalanx distalis is affected most frequently by lesions. They doubt, however, in contrast with $G$ e yer (1979), the effect of the increasing weight-bearing of the lateral claw.

In our country, $L a b i k$ and $P$ e liká $n$ (1975) and $L a b i k$ et al. (1975) were the first to investigate this defect in the progeny of breeding boars of the Preštice breed with the aim of the elucidation of inheritance in this defect. It followed from the pedigree analysis that this anomaly could be characterized as hereditary conditioned probably with recessive way of heredity with a different expression in individual age periods. Hovor $\mathrm{k}$ a (1980a, 1980b) studied "the disharmony of claws" in breeding boars in insemination stations during 1972 - 1979 in dependence on breed pertinence. He has found that the defect appeared in all 
breeds and hybrids in the stations but with a different frequency. The high incidence was found in the Czech large white (CLW) and Belgian landrace (BL) breeds. According to $L o j d a$ and Mrá (1985) the asymmetry of digits affects 30 - $50 \%$ of breeding pigs. The significance of asymmetry in industrial pig production was studied by $K$ a m a $n$ et al. (1986).

By order of the State Veterinary Board of the Czech Ministry of Agriculture and Nutrition (SVS MZVŽ CSR) from 1978 a control of health and health inheritance in stocks of pigs has been set. The defect in the digit development is just one of the defects that are repeatedly found in the control of health and health inheritance. The seriousness of the problem is emphasized by the fact that there have been attempts to conceal this health disturbance in some breedings stocks of pigs, or its mild degree is underestimated and presented as "normal" condition.

In cooperation with the Institute of Veterinary Genetics of the ÚSVú Brno a part of the extensive study on the occurence and seriousness of the digit asymmetry syndrome in usual commercial large stocks of slaughter pigs was realized. The results of this study should form a basis for the project of preventive measures aimed also to find a correlation between sex, type of limb and to solve the problem of objective evaluation of the syndrome of asymmeticy.

Materials and Methods

Research was carried out directly at the slaughtering line of the slaughterhouse on 1702 market pigs including both sows and male castrates from commercial stocks coming from various hinterlands of the slaughterhouse.

The body mass at slaughter ranged within $90^{\circ}-110 \mathrm{~kg}$. The animals were hybrids of breeds produced at the present in our country, mostly originating from the Czech large white (CLW), Landrace ( $L$ ), Belgian landrace (BL) breeds. The changes in morphological formation of not only distal phalanges but also of the whole acropodium and metapodium were investigated; the horny capsula of the claw and of dewclaw was already flayed. It was thus possible to evaluate more objectively not only the length but also the thickness of digits not distorted by the differences of the horny capsula, particularly the size, shape and most of all the pathological changes on individual parts of corium of claw and dewclaw When evaluating the marked characteristics of the digit asymmetry the following classification was used:

- digits symmetrical - representing normal condition when the length and thickness of both chief (III and IV) digits between each other and that of corresponding accessory (II and $V$ ) between each other is virtually equal, the size and shape of the claw symmetrical; the animal treads on both chief digits,

- digits slightly asymmetrical are those when the digits (III and II) are slightly but distinctly shorter, more slender, the claw is slightly 

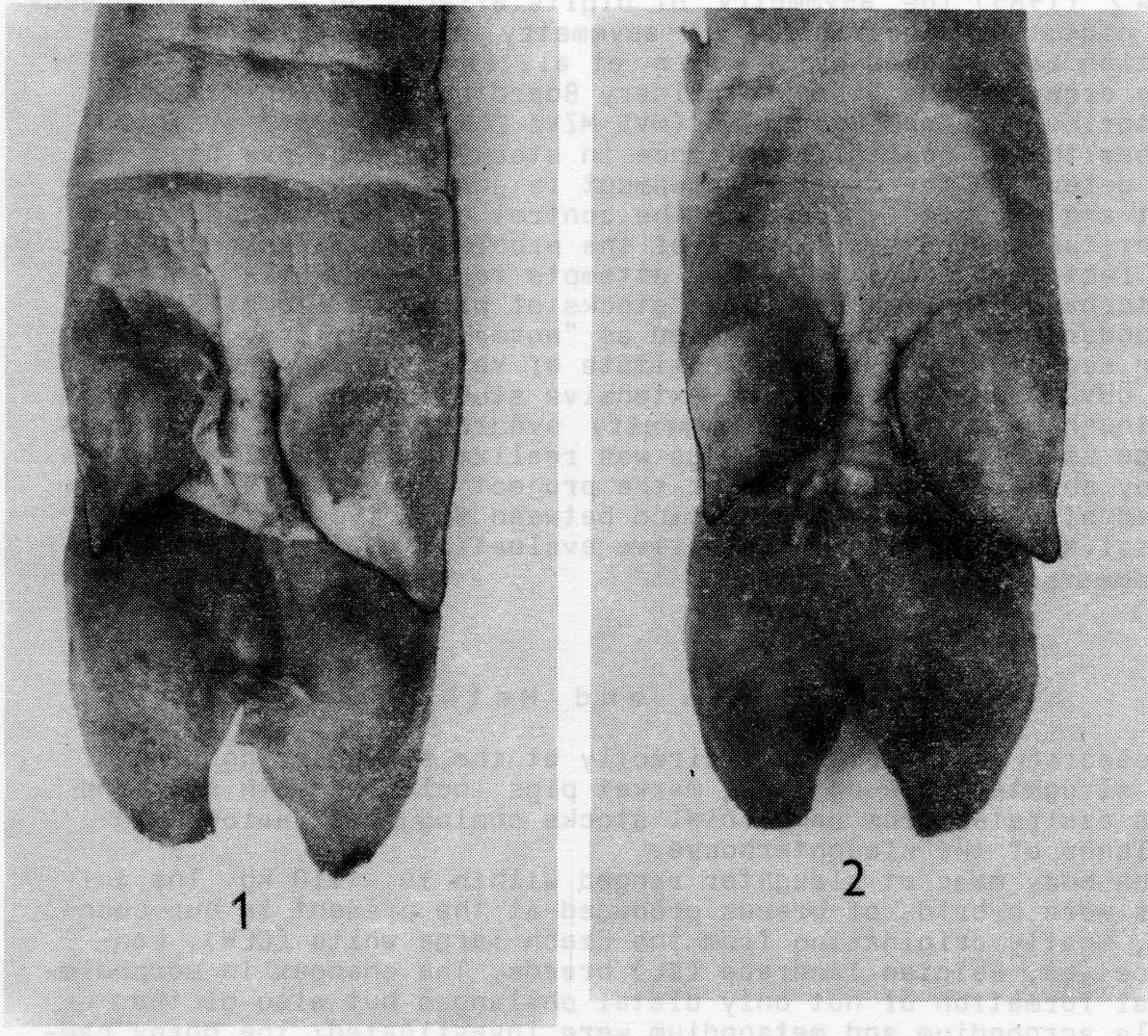

Fig. 1. Autopodium of the right thoracic limb, palmar view. Slight degree of the digit asymmetry. Medial chief (III) and rudimental (II) digits are markedly shorter and thinner than the corresponding lateral digits (IV a V). Tela subcutanea tori of the fourth, more weight-bearing claw, is hypertrophic.

Fig. 2. Similar preparation as in Fig. 1 illustrating the normal condition. Both chief digits reach to the same level. Tori subcutanei are symmetrical, distal phalanges of the same width. 
and the dewclaw even more narrowed and smaller and the animal treads on it only partly or even not at all

- digits markedly asymmetrical - digits III and II are markedly shorter, more slender, particularly the digitus III. Its claw is strikingly narrowed, the circumference changed, the pig does not tread on it. Not infrequently the reaction the corium of the claw and of articulations of the overloaded digit occurs and a various degree of pathological changes appears.

The frequency of the occurrence of the disproportional digit development was then evaluated with regard to sex, body mass, type and number of affected limbs, to the degree of affection and occurrence of further pathological changes in the claw or dewclaw, in association with the corresponding digit, and metacarpus or metatarsus.

Autopodia selected for picture documentation were not only photographed but also $X$-rayed at the Department Roentgenology, University of Veterinary Science Brno, by $d r$. Z. Žert.

Postmortal examination was supplemented from the functional point of view by the intravital evaluation of the digit asymmetry on a smaller number of animals of the studied pig population.

Results and Discussion

The syndrome of the digit asymmetry was found in 797 (46.83\%) of pigs out of the total number of 1702 animals. Slightly asymmetrical digits were observed in 784 cases $(98.37 \%$ ) and the occurrence of markedly asymmetrical digits was noted in 13 pigs $(1.63 \%)$.

In relation to sex the results appeared as follows:

Females - out of the total number of 853 examined sows the changes on both medial digits were found in 405 animals ( $47.48 \%$ ), these being mild in $398(98,27 \%)$ sows and marked in 7 ( $1,73 \%)$ animals. The changes appeared on one, two, three or all four limbs.

In_sows wi th_slightly_ asymmetricical digits the_results _-were

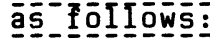

1. The occurrence of asymmetry on one limb only:

1.1. on the right thoracic limb - 15 sows $(3.77 \%)$

1.2. on the left thoracic linb - 16 sows $(4.02 \%)$

1.3. on the right pelvic limb - 34 sows $(8.54 \%)$

1.4. on the left pelvic limb - 41 sows $(10.30 \%)$

Altogether 106 sows were affected on one limb only, i.e. $26.63 \%$.

2. The occurrence of asymmetry on both limbs:

2.1. on thoracic limbs

2.2. on pelvic limbs

- 22 sows ( $5.53 \%$ )

- 81 sows ( $20.35 \%$ ) 


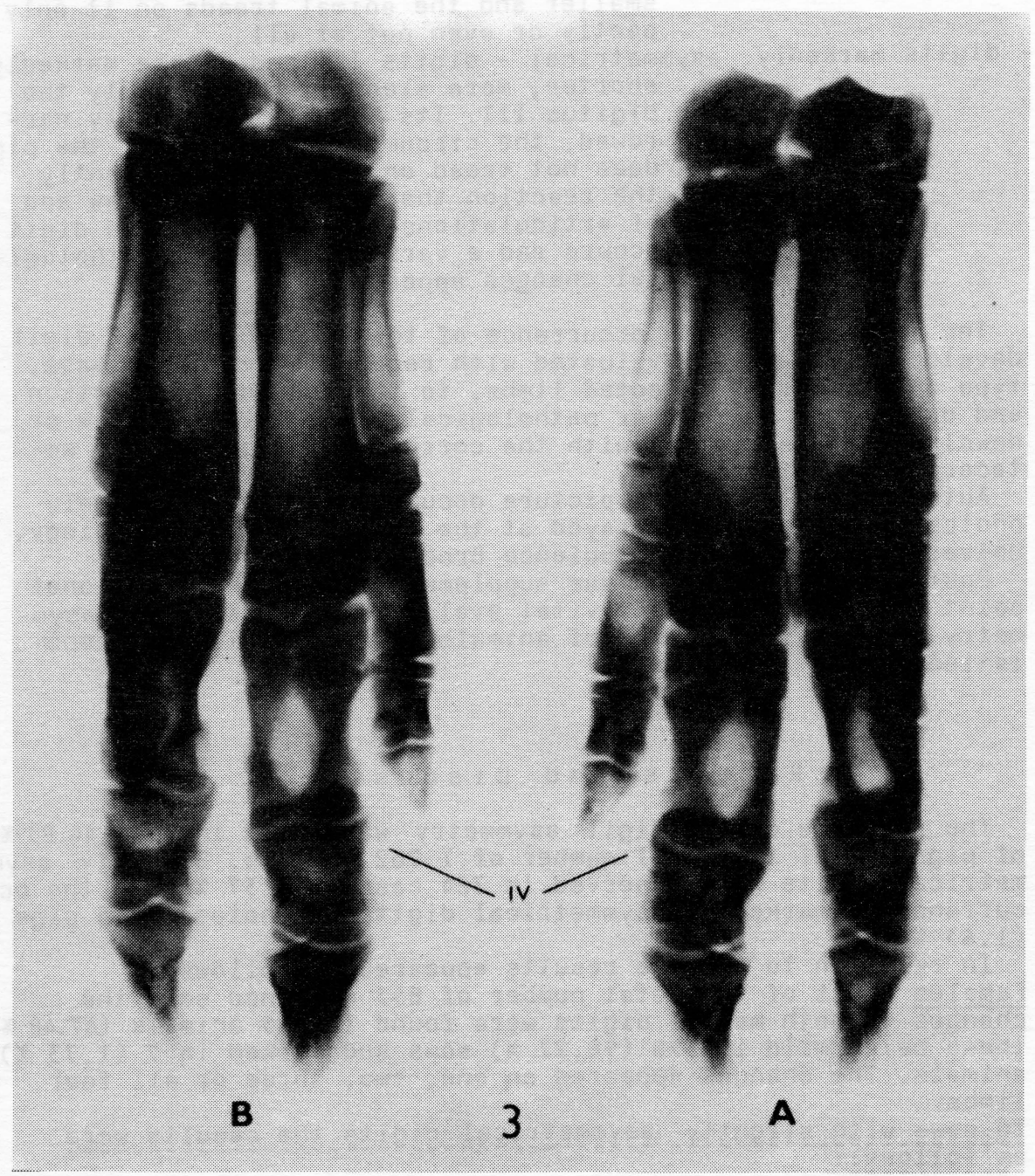

Fig. 3. Roentgenograms of the preceeding preparations. A - rtg corresponds with Fig. 2. Both metacarpi and mutually adequate digit phalanges III and. IV reach to the same level. B - rtg of the preparation on Fig. l, dorso-palmar projection. Slight asymmetry on the preparation is very pronounced on the rtg. Both phalanges of the digit III and metacarpus III do not reach the levels of analogical phalanges of the digit IV and metacarpus IV. Also the disproportion if the stoutness of both chief digits is visible. 
2.3. on one thoracic and one pelvic limb, independently of the side

-42 sows ( $10.55 \%$ )

Altogether 145 sows $(36.43 \%)$ were affected on both limbs.

3. The affection of three limbs:

3.1 . two thoracic out of three limbs - 26 sows $(6.53 \%)$

3.2. two pelvic out of three limbs - 52 sows ( $13.07 \%$ )

Altogether 78 sows were affected on three limbs, i.e. $19.60 \%$.

4. Asymmetry on all four limbs:

This group included 69 sows ( $17.34 \%$ ).

Sows with markediy asymmetrical digits represented only one group since aII the sows were-characterized by the occurrence of the digit asymmetry. on all four limbs.

Male castrates - out of the total number of 849 castrates the dỉgit asymmetry occurred in 392 animals ( $46.17 \%$ ), the asymmetry being mild in $386(98.47 \%)$ and marked in 6 ( $1.53 \%)$ animals.

In male_castrates with_slightly asymmetrícal__digits the re-

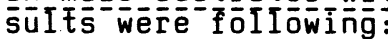

1. The occurrence of the digit asymmetry on one limb only:

1.1. on the right thoracic limb - $22 \operatorname{hogs}(5.70 \%)$

1.2. On the left thoracic limb - 20 hogs ( $5.18 \%$ )

1.3. on the right pelvic limb - 20 hogs ( $5.18 \%)$

1.4. On the left pelvic limb - 25 hogs (6.48\%)

Altogether 87 animals, i.e. $22.54 \%$ were affected with the inequality of digits on one limb.

2 . The occurrence of the asymmetry on two limbs:

2.1. on thoracic limbs only -25 hogs (6.48\%)

2.2. on pelvic limbs only - 64 hogs (16.58\%)

2.3. on one thoracic and one pelvic limb

- 43 hogs ( $11.14 \%$ )

The total number of hogs with both limbs affected represented 132 animals, i.e. $34.17 \%$.

3. The digit asymmetry on three limbs:

3.1. two thoracic out of three limbs - 30 hogs ( $7.77 \%$ )

3.2 . two pelvic out of three limbs - 64 hogs ( $16.58 \%$ )

The total number of male castrates with unequal development of digits on three limbs involved 94 hogs, i.e. $24.35 \%$.

4. The syndrome of the digit asymmetry on all four limbs:

This group included 73 castrates, i.e. $18.91 \%$.

The male castrates with markedly asymmetrical digits constitúte- as weII as in the case of sows, on the group with the digit asymmetry on all four limbs, which included 6 animals ( $1.53 \%)$.

In cases of mild digit asymmetry the pathological changes on the matrix tori of the lateral, overloaded claw were not usually conclusive. In the pronounced form of the asymmetry we have occassionally found marked redness with increased hyperemia, serous to hemorrhagic effusion, particularly of the matrix tori (Fig. 5) and of the matrix parietis, or with small hemorrhages; sporadically, the manifestations of suppurative inflammation or of panaritium were observed. Not only the medial claw but also the whole digit III were found to be markedly narrower and smaller, as was demonstrated 


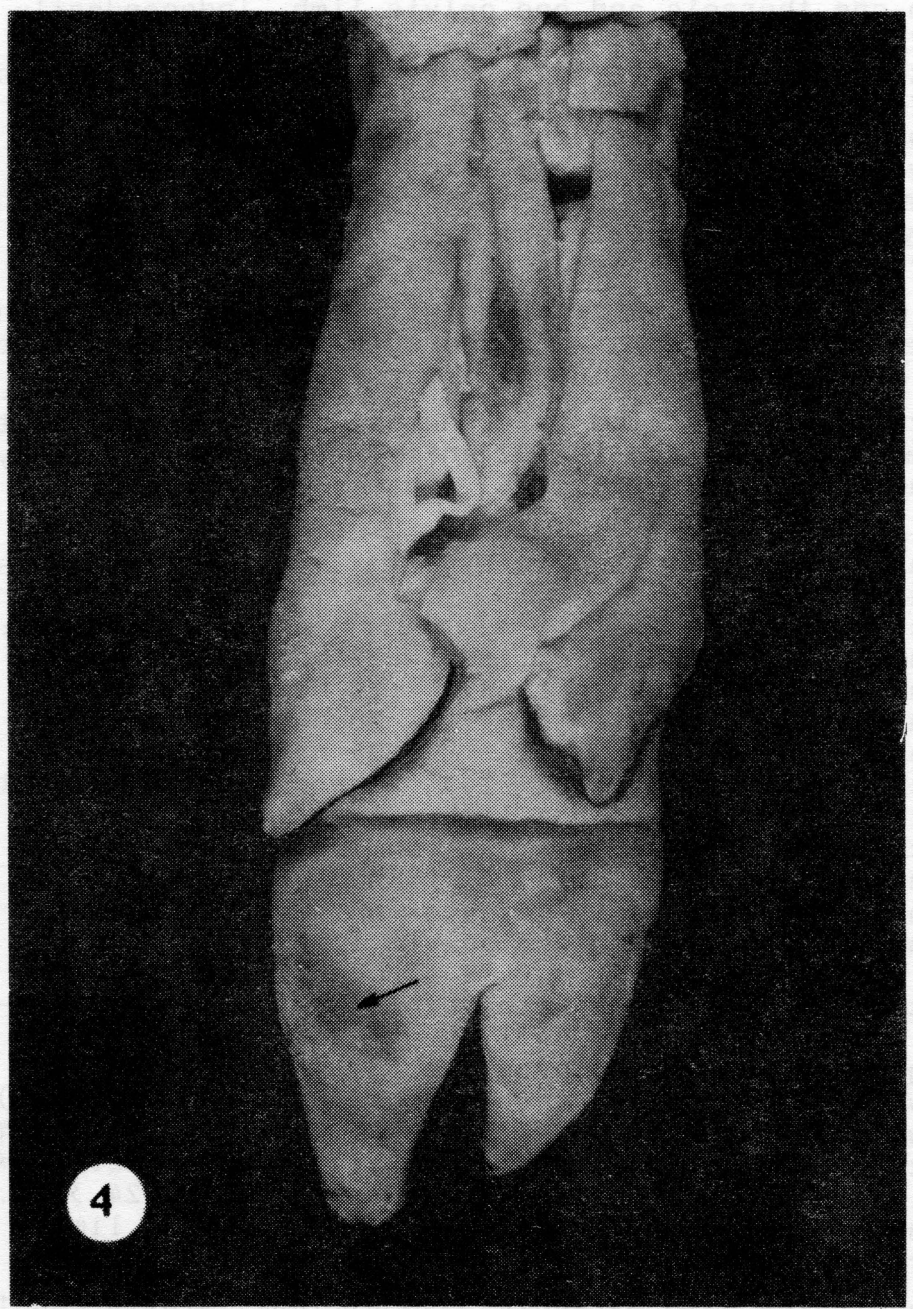

Fig. 4. Autopodium of the left pelvic limb, plantar view. High degree of the asymmetiy of chief and rudimental digits. Tela subcutanea tori of the lateral phalanx distalis is swollen with a demarked inflammation. Matrix tori swollen, hyperemic, hemorrhagically infiltrated. 
by roentgenograms (Figs. 3, 6). They also show that mutually adequate phalanges and bones of metapodium with the autopodium being within the standard, reach essentially to the same level, regularly sagittaly oriented with regular position of the articular surfaces. When, on the other hand, the asymmetry syndrome is present, the digitus IV is slightly S-deformed (Figs. 3, 6) which results in obviously pathological condition and pathological function of the digit articulations. It is also evident from the roentgenograms that the digit asymmetry does not concern the claw morphology only, not even the digits only, but it concerns also the metapodium.

It follows from the presented data that the asymmetry syndrome occurs both in females and in male castrates, the occurrence being conclusively more frequent on the pelvic limbs than on the thoracic ones. It occurs in all groups according to the number of affected limbs, the difference being higher in males. The only exception has been observed in the group 1.1. in the case of male castrates where the occurrence of the asymmetry syndrome was found to be slightly more frequent, i.e. by $0.52 \%$, on the right thoracic $(22: 20)$ than on the right pelvic limb.

Moreover, it is striking that the difference in the occurrence of asymmetry between thoracic and pelvic limbs was found to be substantially higher in females than in male castrates. So, in sows of the group 2.2. the incidence on the pelvic limbs was found to be four times higher than that on the thoracic limbs.

The results show in a number of respects a remarkable consistency which is manifested by almost identical values or by small differences particularly as to the following aspects:

- the frequency of the digit asymmetry incidence in the groups $1.1 ., 1.2$. both in sows and hogs, and of mutual ratio of the groups 1.1.: 1.2.;

- similar ratios (essehtially characterizing also the groups 2.1., 2.2. in both animal categories), expressing the greater affection of the pelvic limbs which dominates over that of the thoracic ones in females; nevertheless, this difference was found to be high also in the case of male castrates as follows from the survey;

- finally, a remarkable agreement was observed in the groups $3.1 ., 3.2$. both in the relationship between the affected thoracic and pelvic limbs and in the ratio between the incidence of the syndrome in sows and hogs.

It follows from the comparison of the examined sows (853) and of male castrates ( 849 ) that the incidence of the asymmetry in sows $(47.48 \%)$ and in hogs $(46.17 \%)$ is almost identical. This occurrence was found to be similar as far as the limb affection is concerned. If the asymmetry was found on one limb only then the ratio of females to castrates was $27: 23$, if on both limbs, $26: 34$, if on three limbs, $19: 24$ and if on four limbs then the ratio was $17: 20$.

An even occurrence of the asymmetry syndrome in sows and hogs points to the important fact that this hereditary defect (Nordby 1939), the modus of which was elucidated by $L$ a bik and pelikán (1975) in tris country, is probably not 


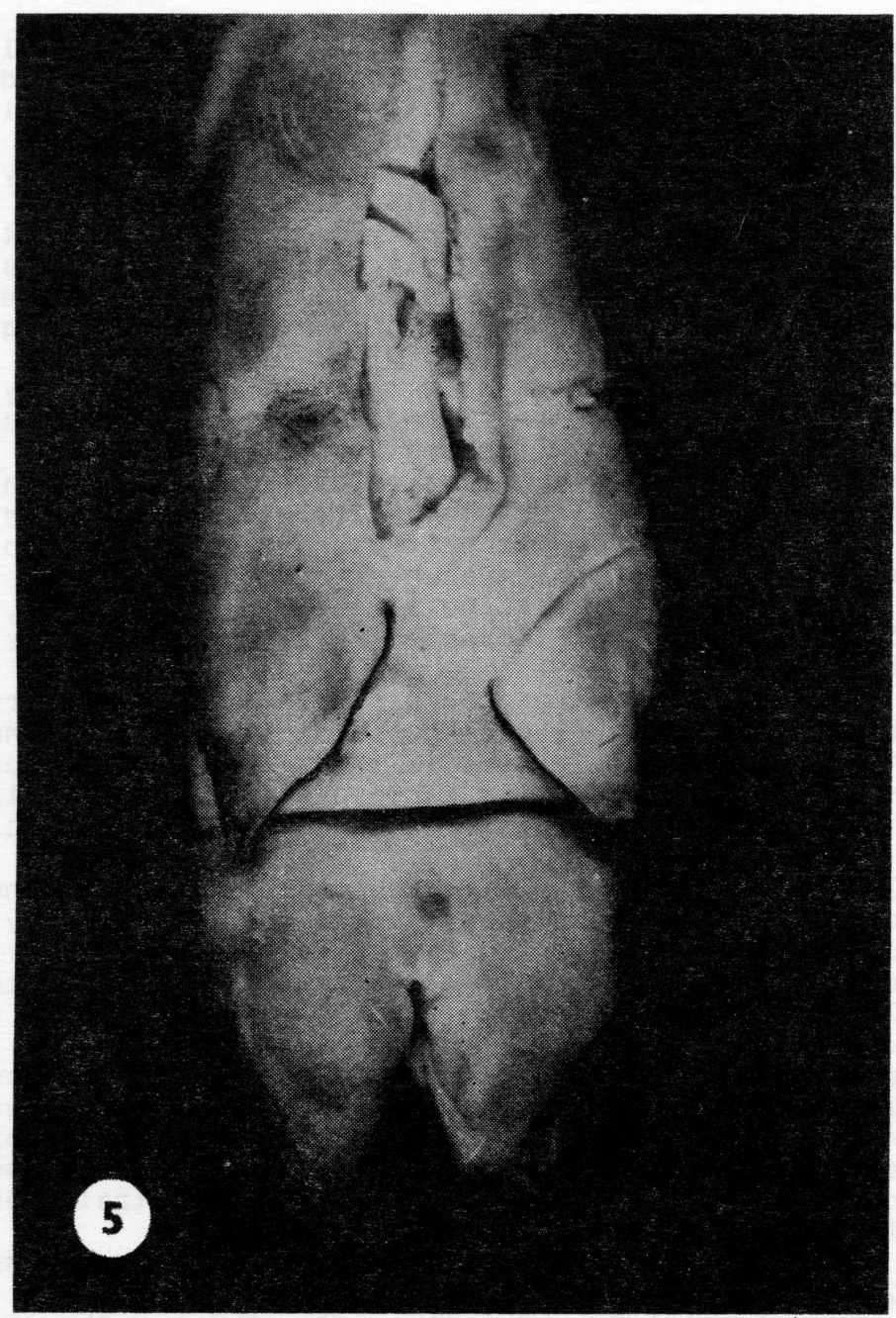

Fig. 5. Autopodium of the right pelvic limb with a symmetrically developed chief and rudimental digits without apparent pathological changes. 
associated with the sex of animals. The fact, that until now this defect has been described mostly in breeding boars, follows probably from more demanding requirements on healthy limbs of boars on one hand and from an insufficient attention paid to this requirement in other types of production, from insufficient information on this anomaly and from underestimation of a milder degree of this defect (regarded as normal condition) on the other hand. Certain unsuitable types of floor may undoubtedly play a role in the development of the asymmetry. The reason why our numerous results obtained from various groups are so consistent can be seen in a relative homogeneity of management conditions of commercial animal husbandry.

On the other hand, a considerable difference is seen when the comparison is made of our results with those obtained by $\mathrm{HO}_{\mathrm{O}}$ vorka (1980), particularly as to the percentage of pigs with pronounced asymmetry. This can be explained by a relatively low age of animals examined by us, although $L a b i k$ and $P e-$ likán (1975), S $\mathrm{mith}$ and Mitchel l (1977) refer on the asymmetry signs already in suckling piglets. Hovorka (1980) further reports that inexpressive asymmetry observed in 8 months of age changes in $100 \%$ of cases within a period of six to twelve months to a pronounced inequality with the development of pathological changes not only on a claw but also on articulations of the whole digit with a differing degree of motility disturbances. Culling represents $23 \%$. This high frequency of the asymmetry syndrome was observed in CLW and $B L$ breeds. The fact that in the hybridization program the $C L W$ breed forms a basis of the maternal lines and the BL breed is a basis of all hybrid boars used at present for the production of final slaughter pig ( $L \times B L, B L \times D, B L \times H)$ appears to be serious. The defect is encountered in all breeds and hybrids but with a different frequency ( $\mathrm{H}$ o v O r k a 1980). In slaughter pigs it causes the decrease in body mass gains and premature slaughter ( $L$ a b ik, P e l i kán 1975), thus leading to a negative selection, which was apparently reflected also in our results since it can be presumed that animals with marked asymmetry were already culled during fattening prior to reaching the slaughtering weight. This and a relative low age of slaugher animals are the reasons of the mild form of asymmetry being observed in our study.

Several times higher occurrence of the asymmetry syndrome on pelvic limbs is in accordance with the results published by Hovorka $(1980)$. We suppose that this occurrence is associated, besides other factors (hereditary predisposition, unsuitable floors, etc.) mostly with a one-sided selection of meat breeds of pigs towards a higher body length and an enormous musculature of body parts leading to nonphysiological or even pathological posture, to pathomorphological changes on articulations and bones of autopodium, and to difficulties when walking and standing. In boars, specific load of the pelvic limbs appears at siring.

The fact cannot be however overlooked that Nordby (1939), who first referred on the digit asymmetry in swine, observed this syndrome already in the thirties, i.e. at the beginning of the development of meat breeds of pigs. From the extensive 


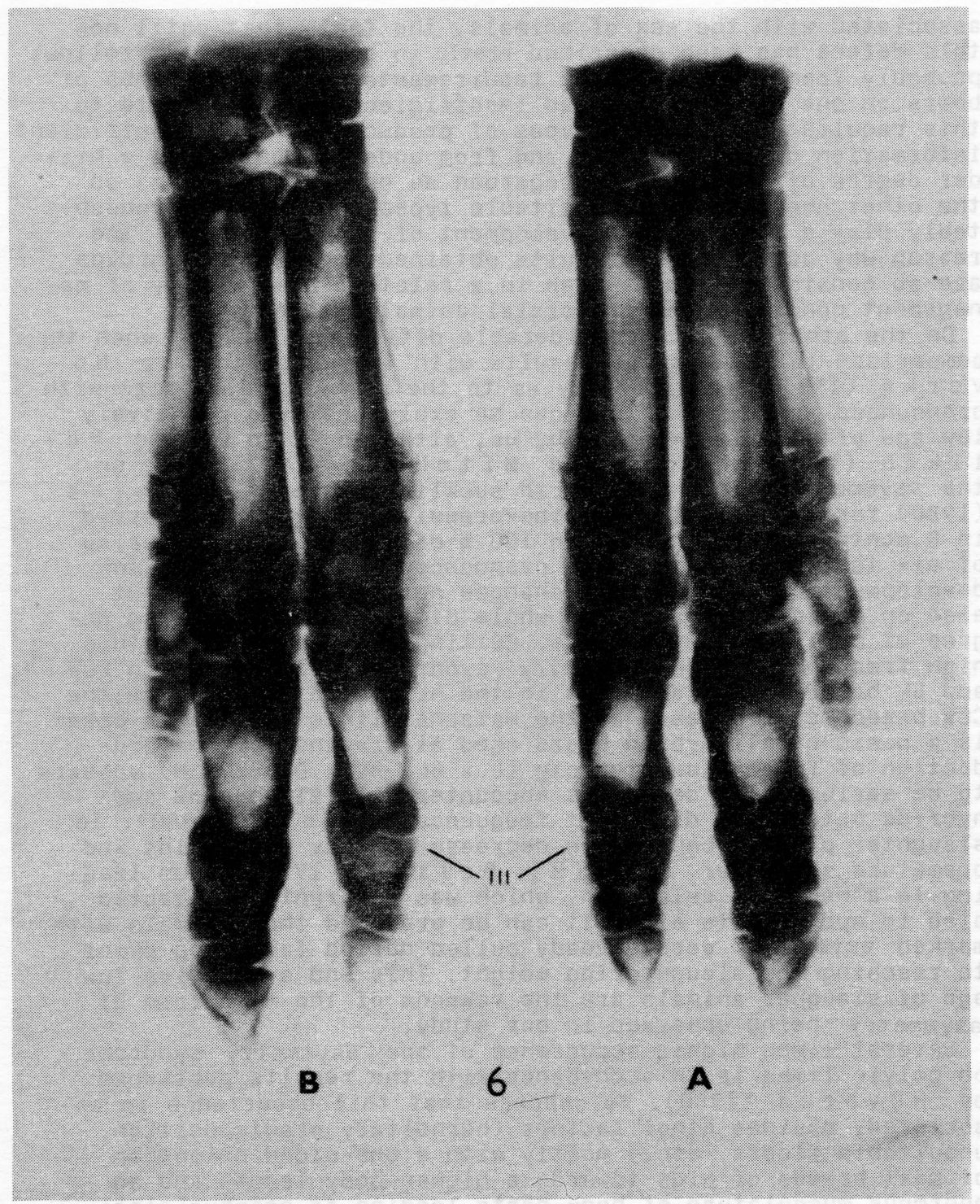

Fig. 6. Roentgenograms of the preparatiuns illustrated in Figs. 4 and 5, dorso-palmar view. A - rtg corresponding with Fig. 5; metatarsi and digits of the same length, regular configuration, third digit appears distally slightly thinner. B - rtg fully illustrates Fig. 4, strong disproportion not only between the digit III and IV but also between the metatarsi. Overall marked shortening of the dinit III is apparent also by the appearance of light spot on the roentgenogram. 
study, into which hundreds of boars of various breeds and coming from various parts of the U.S.A. were included, he concludes that he observed a relatively low number of cases in which the phalanges of chief digits were of the same size. From a detailed study of 40 limbs selected randomly from a slaughtering plant he found in all of them a different degree of variations in digits, the medial chief digit (III) being in extreme cases by $4 \mathrm{~cm}$ shorter than the lateral one (IV).

Nordby regards the digit asymmetry syndrome to be a hereditary conditioned defect. In a genetic experiment conducted the sows with a slight digit asymmetry sired by boars with marked inequalities of digits had progeny with pronounced asymmetry, even in the case of mating of parents with a slight asymmetry syndrome. He did not, contrary to $L$ a b $1 K$ and $P e-$ likán (1975), determine the heredity modus. He admits, however, the physiological variation by saying: "the variation in the length of the toes is no doubt what Sisson had observed". He supports this by a reproduction of figures presented by Sisson, showing the skeleton of autopodium of a thoracic limb with a mild asymmetry and of a pelvic limb with a marked asymmetry. The latter condition was however presented by Sisson as a normal anatomical condition. Neither in this text nor in later edition ( $S$ is s o $n$ 1947) this variation is discussed. He mentions only that the metacarpus III is stouter than the metacarpus IV, and the metacarpus $V$ is stouter than the metacarpus II, and that the digit phalanges are similar to those in cattle.

This is a very serious and essential question since we are to evaluate the digit asymmetry without knowing the standard. Necessary data defining the normal state, i.e. length, thickness and mutual relationship, especially of the principal (III and IV) metacarpus and of pig digits are missing or contradictory not only in textbooks of veterinary anatomy but also in voluminous, of several volumes comprised books on veterinary anatomy. They cannot be found in special works on osteology (Kolda 1936) either. As far as the thoracic limb is concerned a laconic statement is most frequently encountered that the metapodium is formed by four (II - V) metacarpi, out of which two chief ones are longer and at least three times thicker than the remaining two accessory metacarpi (Ak a jevskij 1975; Koch 1976). Sisson (1947) adds that the metacarpus III is stouter than the metacarpus IV but he does not mention a mutual relationship as far as the length is concerned. Kold a (1936) and Barone (1966) describe os metacarpale III as being not only thicker but also longer than os metacarpale IV. El lenberger and $B$ a um (1921) are of contradictory opinion saying that os metacarpale IV runs more distally to digits.

According to Sisson (1947) and Kolda (1936) the os metacarpale $V$ is the thickest out of accessory metacarpal bones but shorter than os metacarpale II (K o I d a 1936). On the other hand, according to El lenberger and $B$ a um (1921) the former is longer than the latter.

As $f a r$ as the digits are concerned the majority of authors (Ellenberger, Baum 1943; Sisson 1947; Akajev- 
skij 1975; Koch 1976; Kaman 1980)restrict themselves to claim the existence of two chief digits (III and IV) on which the pig treads and of two accessory ones that the pig does not usually use. Kolda (1936) adds that the proximal phalanges of the chief digits are of the same thickness but two times longer than the medial ones ( $\mathrm{Nickel}$ et al. 1968). None of them mentions the length of the principal digits, or the variability in length or thickness of the third and fourth digit or the mutual disproportion, even though it may be concluded from the statement that the pig treads on both chief digit that both are of the same length. On the other hand, the digitus II is according to $\mathrm{Kolda}(1936)$ and $\mathrm{B}$ a r o ne (1966) longer than the digitus $V$, which is indeed contrary to the above presented finding of Ellenberger and B a um (1943).

Certain morphometrical data on individual digit spoke and their mutual relationship on thoracic limbs could be found or deduced from the illustrations of the bone basis of meta- and acropodium. The majoritiy of authors (El l enberger, Baum 1943; Barone 1966; Popesko 1968; Akajevskij 1975; Kaman 1980; Koch, Berg 1985) present both principal metacarpi and digits (III and IV) as being of the same length or their identical length could be deduced from the figure (Ko 1 d a 1936). On the other hand, Sis s on (1947) and Ni cke 1 et al. (1968) illustrate clearly, even though slightly, the metacarpus IV and digitus IV as being longer and the phalanx distalis being larger than the digitus III.

Differences were found even as to the metacarpus and digitus II and $V$. $K a m a n ~(1980)$ and $K o C h$ and $B$ erg (1985) present the digitus II as being somewhat longer than the digitus $v$. El lenberger, Baum (1943), Nickel et al. (1968) and $S$ is s on (1947) present the digitus $V$ as being longer and the digitus II shorter whereas Popesko (1968) claims that both accessory digits are of the same length.

As $f a r$ as metatarsi are concerned, they are mostly compared to metacarpi and are considered to be longer and thinner (E 1 lenberger, Baum 1943; Kolda 1936; Sisson 1947; Cer vený 1980; Koch, Berg 1985). Only Nickel et al. (1968) specifies that they are, on the contrary, thicker than metacarpi. According to Kolda (1936) and Sisson (1947) the third metatarsus is thicker than the fourth one. Many authors agree with the statement that the os metatarsale IV is longer than the os metatarsale III (Kold a 1936; B a r o n e 1966; Akajevskij 1975). Also sisson (1947) and Červeny (1980) describe them as more distally running.

Similarly, the digital bones of the pig pelvic limbs are by the above mentioned authors altogether analogized with the relationship on thoracic limbs, saying that they are, similarly as metatarsi, thinner and longer.

From the fact that the os metatarsale IV runs more distally, or is longer than the os metatarsale. III, it follows that the digitus IV, on the assumption of equal development of digital bones of both principal digits, must necessarily run more distally than the digitus III, thus manifesting itself by asymmetry, already under "normal" anatomical conditions and with all consequences. 
In the case of regularly formed pig limb the body mass is supported evenly by both chief digits. If one of them is longer or shorter, they do not have even and equivalent contact with the ground and a greater part of the whole support takes over the longer digitus. This situation appears to be definitely pathological with all the consequences including the deformation of articular surface and digit phalanges. Out of both chief digits, the fourth digit was found by us to be longer, or strictly speaking, more distally running. Its greater length can however be relative, caused by relatively or actually longer metapodial bone IV or by relative shortening of the third digit due to its insufficient or altogether missing support of weight. On the other hand, functional hypertrophy of the digit IV could also be admitted. This question cannot however be answered without the aimed morphometrical and histopathological study.

Our roentigenogram of the digit asymmetry of the unaffected autopodium (Fig. 3) shows clearly that both chief metacarpi run distally in fact to the same level. Similarly, as to the length of digit phalanges of both chief digits, they are according to roentgenogram equally developed, both digits reaching to the same level, thus being of the same length. Our findings are therefore contradictory not only with those of $\mathrm{Kolda}$ (1936) and $\mathrm{B}$ a r o $\mathrm{ne}$ (1966) in that the metacarpus III of the pig is longer than the metacarpus IV but also with the findings of E $11 \mathrm{e} \mathrm{n}$ berger, Ba um (1943). According to the latter, the metacarpus IV is the longer one. As follows from the roentgenogram (fig. 3), this condition, i.e. the longer metacarpus IV was found by us when the asymmetry syndrome was established.

On the other hand, our roentgenological demonstration of the same length of the digit III and IV in the pig is confirmed not. only by the graphical illustration of this mutual relationship by a number of authors (Elle nberger, B a um 1943; B a r one 1966; Popesko 1968; Akajevskij 1975; Kaman 1980; Koch, Berg 1985) but also by a verbal statement of Sis on (1947) provided that treading on both chief digits is interpreted as identical length of these digits.

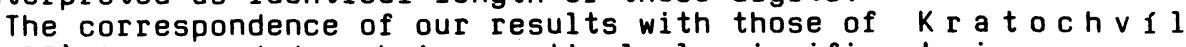
(1973) is regarded as being particularly significant since, contrary to $\mathrm{Padelt}$ (1892) and $\mathrm{Huser}$ (1930), this author carried out morphometrical measurements of acropodium on current up-to-date Czech large white breed. It follows from the results obtained by him that both chief digits (III and IV) in the pig are of the same length, even with regard to the sex differentiation and the comparison with the wild boar; occurring smaller differences were not statistically significant. Our findings were found to be in accordance with the observation of the digitus IV which appeared to be consistently stouter in the domestic pig. This, according to our opinion, favours for a higher functional weight load of the digit IV, especially in meat breeds. In the wild boar, the digitus IV is according to Kratochvil (1973) slightly thinner, this being however not statistically significant.

If we compare our findings on native preparations of pelvic limb autopodium of pigs not affected by the digit asymmetry syn- 
drome (Fig. 4) and the finding on roentgenograms of these preparations (Fig. 6) with the presented literature data, then contrary to the latter, both chief metatarsi and both chief digits when of the same length should be regarded as a standard; the condition with slightly indicated tendency to the longer metatarsus IV and digitus IV and somewhat more marked tendency to the more thicker digitus IV, which is evident particularly from the roentgenogram of the phalanx distalis (Fig. 6), is considered as being within the framework of variation. Higher functional weight support of the fourth digit, obviously in the condition when both chief digits reach to the same level, in the condition of non-pronounced asymmetry, could lead to a various degree of impairment of the physiological configuration of phalanges of the fourth digitus and its axis. It is, however, problematic to determine the state which is still considered as the variation and that which is already pathological without possessing exact metrical data.

Our morphological observation on the pelvic limb corresponds strikingly with the metrical results of Kratochvil (1973) although this author, assessed, even on the pelvic limb, the morphometry of phalanges (acropodia) only. According to the values obtained by him the digit III and IV of both sexes are of the same length both in domestic and in wild pig. A certain tendency to the longer third digit in the domestic pig and on the other hand to a shorter one in the wild pig was not statistically significant. As far as the thickness of the digits is concerned, the digit IV is conclusively thicker than the digit III in both sexes of the domestic pig. The differences in the wild pig are less significant; they are, however, highly significant both in domestic and wild pig as far as the phalanx media is concerned.

The presented characteristics of the normal condition contrast strongly with significantly longer not only metatarsus IV but also with the digit IV on the autopodium with asymmetry appearing both on the preparation and on the roentgenogram to be markedly stouter, particularly in the case of the claw, thus altogether markediy more developed than the metatarsus and digitus III. The second digit is shorter than the fifth one both in thoracic and pelvic limb, the both accessory digits being relatively longer in the pelvic than in the thoracic limb.

It is true that Schneider and $Z$ intzsch (1962) were engaged by the determination of optimal areas for lead anesthesia on pig limbs but their work is primarily an anatomical one which is related to our problem. On figures illustrating the topographical situation on autopodia of thoracic limbs both chief (III and IV) digits are of the same stoutness. Correspondingly, as far as the length and thickness are concerned, the chief digits on the pelvic limb are illustrated. The differences in the length of the digitus II and $V$ were insignificant. The photograph of the thoracic limb autopodium of a very young animal shows the second digit as being distinctly shorter than the fifth one and a somewhat shorter third digit.

Also the anatomical study of the tendon sheath and the bursa conducted by $\mathrm{Ni}$ is e $\mathrm{I}$ (1967) on "Dannish market pig" appears to be relevant. Although she studied young animals up to one year 
of age, similarly as Schneidér and $Z$ intzsch (1962), the data on the length and formation of the digits differ strikingly from the illustration presented by the above mentioned authors. Although the digit II of the thoracic limb appears essentially to be of the same length as the digit IV, it is, ho- wever, distinctly thinner. The main difference can be seen on the pelvic limb where all the three phalanges of the third digit are substantially thinner than those of the fourth one and the third digit is markedly shorter. The digit II with regard to the digit $V$ is considerably shorter both on pelvic and thoracic limb.

The asymmetry found by us in the outstanding manual on pathologico-anatomical dissection of farm animals (B 011 1957) appears to be in context with the presented data and the digit asymmetry syndrome in the pig. On photographs (p. 169, Fig. 76) showing dermal erosions on the acropodium of the pig suffering from foot-and-mouth disease a slight asymmetry of the chief digits of the thoracic limb and a pronounced asymmetry on the pelvic limb are clearly demonstrated.

One cannot avoid considering the causes of many confusions and discrepancies in morphological characteristics of the pig metapodium and acropodium, particularly as far as the length and thickness of individual bone spokes are concerned. The fact that special works are missing concerned with this topic appears to be most serious. The results should be based on a sufficient material obtained on progressive modern breeds. The research workers have been more attracted by the comparison of the skeleton of the domestic and wild pig ( $P$ a de $1 \mathrm{t}$ 1892). Huser (1930) tried to cover the differentiation on the skeleton of both these pig species due to domestication. He however used primitive breeds of the domestic pig, and for this reason he has not found any "changes worth mentioning". Recently, K r a tochvil. (1973) statistically evaluated a series of parameters on the skeleton of the autopodium of the present Czech large white breed and of the wild pig, which he examined from the morphological and morphometrical points of view.

However, even this study, despite its exactness, does not provide necessary data for the objective evaluation of the asymmetry syndrome since Kratochvil (1973) evaluated individual phalanges of the acropodium only. The functional length of individual digits is not identical with the mere sum of lengths of the digit phalanges but is influenced also by the length of corresponding metacarpus or. metatarsus. Despite this, the evaluation published by $K r a t o c h v i l$ is very valuable for the assessment of the digit asymmetry, the data correspond with our findings on limbs not affected by the digit asymmetry and together with them favour the statement saying that the digit III and IV reaching distally to the same level and forming a functional unity should be regarded as a normal morphological and physiological condition.

The symmetry of both chief digits in the pig is supported also by $G$ eyer (1979) in his study on morphology and growth of the phalanx distalis in the pig. The more pronounced deviations from the symmetry should be regarded as an anomaly, as a pathological condition. Ge yer (1979) has found that in seven months old wild pig ( $40 \mathrm{~kg}$ ) the medial phalanx distalis of thoracic limbs 
are roughly of the same size as the lateral ones but as $f$ ar as the pelvic limbs are concerned the medial distal phalanges are only slightly larger than the lateral ones. In the newborn domestic pig, and still at the age of 1 - 2 weeks, the sole surface of the medial distal claw was found to be of the same size as that of the lateral one. When the animals are housed on hard floors, the sole surface of the lateral claw gradually becomes substantially larger with increasing body mass of pigs when compared with the medial claw.

The contribution of $L o j d a$ and Mrá $z$ (1985) called "hereditary asymmetry of the development of the $3 \mathrm{rd}$ and 4 th toe in pigs causing locomotory disorders" is controversial with our observations and with literature data. The authors point out that 30 - 50 percent of culled breeding pigs is a result of this health disturbance. They correctly state that the asymmetry syndrome affects the skeleton of the whole acropodium and metapodium. Their characteristics of the pathogenesis of this anomaly is not, however, quite clear, the deductions are inaccurate and even illogical thus leading to the statement "that the 3 rd digit is bearing more weight than the 4 th one and the whole weight is transfered on one half of each limb only". Thus, further hypertrophy of the whole skeleton of the 3rd digit and the atrophy of the whole part of the 4 th digit appear". This is contradictory not only to our observations but also to findings of other authors.

The digit asymmetiy in the pig is not infrequently by some authors understood and interpreted as an anomaly of claws or dewclaws only ( $L$ ema $n$ et al. 1981; L a bik, Pelikán 1975; La bik et al. 1975; Hovorka 1980a, 1980b). Particularly the classification of this anomaly as "the disharmony of claws" ( $L$ abik, Pelikán 1975; Labik et al. 1975; Hovorka $1980 \mathrm{a}, 1980 \mathrm{~b})$ is not realistic and correct. For this reason we suggest to use further the term "the syndrome of asymmetry or inequality of the digits". Although the genetically conditioned health disturbance of considerable breeding and economic significance is involved, it is relatively little known, this being demonstrated by the fact that this defect is not even described in the Veterinary Orthopedics (Orság et al. 1985).

Su m m a r y

The fact that 797 slaugher pigs, i.e. $46.83 \%$, out of 1702 examined at a usual slaughter house for an occurrence of the digit asymmetry, were affected on one limb at least points out to a great relevance of this observation for our industrial pig production since this defect is genetically conditioned with a different expression in individual development periods. This expression could be affected also by other influences, e.g. one-sided selection for extreme musculature and the technology of production. The frequency of the occurrence of the asymmetry in relation to sex was comparable but in relation to limbs the incidence on pelvic limbs was found to be several times higher than on thoracic limbs. This anomaly in digits showed a high occurrence also in breeding causing considerable breeding and economic loss 
by culling of high percentage of animals due to serious secondary pathological changes on autopodia and to motility disorders. In commercial animal husbandry it decreases the body mass gains and leads to premature slaughter.

The milder expressivity of changes in fattening animals in comparison with the breeding pigs was caused by the lower age of the former and thus by a milder development of the asymmetry.

The results obtained complement the small number of literature data on the digit asymmetry syndrome in pigs not only in our country but also from the viewpoint of world literature. This anomaly escapes the attention due both to ignorance of it and to a lack of precise information on morphometrical parameters of the pig autopodium and the way of evaluation of less pronounced digit asymmetry as being "normal condition"; not infrequently the concealment of this genetical defect occurs.

For the elimination of the digit inequality in the pig an attitude should be adopted both from the genetical point of view using the methods of positive and negative selection and breeding aimed at a more suitable body frame to obtain physiological posture of breeding animals and also by the construction of floors in stables that would not contribute to the development of the defect and the consequences resulting from it.

\section{Syndrom asymetrie prstů a frekvence jeho výskytu} u jatečných prasat

Asymetrii prstú jsme sledovali patomorfologicky a rentgenologicky na porážkové lince běžných jatek u hybridnich prasniček a samčích kastrátú převážně plemen Large white, Landrace a Belgian landrace o hmotnosti $90-110 \mathrm{~kg}$. Výsledky dokumentují závažnost této geneticky podmíněné anomálie i u jatečných prasat vzhledem $k$ patomorfologickým změnám a jejich funkčním a ekonomickým dủsledkủm. Rủzný stupeñ změn, postihujících 1-4 končetiny, jsme zjistili u $797(46,37 \%)$ z 1702 sledovaných; pŕibližně stejně často u prasniček $(47,48 \%)$ i vepřu $(46,17 \%)$.

U 26,63\% prasniček byla postižena pouze jedna končetina (RT $3,77 \%$, LT - 4,02, RP - 8,54\%, LP - 10,30\%); u 36,43\% dvě končetiny ( $T-5,53 \%, P-20,35 \%$, jedna hrudní a jedna pánevní nezávisle na straně - 10,55\%); u 19,60\% tři končetiny (ze trí 2 hrudní - $6.53 \%$, ze trí 2 pánevní - 13,07\%) a u 17,34\% čtyři končetiny.

U 22,54\% vepřu byla postižena pouze jedna končetina (RT $5,70 \%, L T-5,18 \%, R P-5,18 \%, L P-6,48 \%) ; u 34,17 \%$ dvě končetiny ( $T-6,48 \%, P-16,58 \%$, jedna hrudní a jedna pánevní nezávisle na straně - $11,14 \%$ ); u $24,35 \%$ tři končetiny ( $z$ toho dvě hrudni - 7,77\%, dvè pạnevní - 16,58 \%) a u 18,91\% čtyři končetiny ( $R=$ pravá, $L=$ levá, $T$ - hrudní, $P$ = pánevní).

Asymetrie na pánevních končetinách byla nejen podstatně častějši, ale i výraznější než. na končetinách hrudních. Celkově její mírnějši stupeñ u jatečných prasat, než je popisován u plemenných prasat, souvisí s jejich relativně nižšim věkem. Jsou diskutovány jednak nedostatečné, jednak rozporné literární údaje o nor- 
málni morfologii autopodia prasete $z$ hlediska objektivního posuzováni asymetrie prstú a faktory prispivajíci k jejimu vzniku.

syndromem asymetrie rozumime morfologickou disproporci predevším mezi oběma hlavními prsty. Digitus.III. je vždy celkově ménè vyvinutý, zatěžován cástečně nebo vủbec. Rủzný stupeñ patologických změn na IV. prstu následkem pretěžování vyústuje $v$ rúznè intenzivní pohybové poruchy.

\section{Синдром асимметрии пальцев и частота его наличия у боенских свинеи}

Асимметрию пальцев исследовали патоморфологически и рентгенологически на боенской линии обычной бойны $у$ гибридных свинох и кастратов самцев преимушественно породы Large white, Land race и Belgian Lanđrace массой 90-110 кг. Результаты документируют важность упомянутой генетически обусловленной аномалии также у боенских свиней по отношению патоморфологическим изменениям и их фунхционально-экономическим последствиям. Разный уровень изменений, поражающих 1 - 4 конечности, был нами установлен у $797(46,378)$ из 1702 исследуемых животных; приблизительно С одинаковой частотой у свинох $(47,488)$ и хряков $(46,178)$.

У 26,68 свинок была поражена лишь одна конечность (РТ 3,778 , ЛТ - 4,028, РП - 8,58, ЛП - 10,308); у 36,48 свинох две конечности $(\mathrm{T}-5,538, \Pi-20,358$, одна грудная и одна тазовая независимо от стороны - 10,558); у 19,608 - три конечности (из трех 2 грудные - 6,538, из трех 2 тазовые - 13,078) и у 17,348 - четыре конечности.

у 22,548 хряков была поражена лищь одна конечность (РТ 5,708 , ЛТ - 5,188, РП - 5,188, ЛП - 6,488); у 34,178 хряков две хонечности $(\mathrm{T}-6,488, \Pi-16,588$, одна грудная и одна тазовая независимо от стороны - 11,148$)$; у 24,358 - три конечности (из этого две грудные - 7,778 , две тазовые - 16,588) и у 18,98 - четыре хонечности.

Асимметрия тазовых конечностей встречалась не только гораздо чаще, но и выразительнее по сравнению с грудными конечностями. Ее более умеренный уровень у боенских свиней в сопоставлении с племенными связан с их сравнительно небольшим возрастом. Обсуждаются недостаточные и противоречивые литературные данные, связанные с нормальной морфологией аутоподия свиней с точки зрения объективной оценки асимметрии пальцев и факторы, способствующие ее возникновению.

Под синдромом асимметрии подразумеваем морфологическую диспропорцию прежде всего между обоими главными пальцами Палец ШI в общем менее развит, находится под частичной нагрузхой или нагрузка вовсе отсутствует. Разная ступень патологических изменений 1У пальца в результате перегрузки выливается в нарушение двигательных способностей разной интенсивности.

$$
\text { P - правая. Л - левая, Т - грудная, П - тазовая. }
$$


AKAJEVSKIJ, A. I.: Anatomija domašnych životnych. Kolos, Moskva, 1975.

AMRUD, A. J.: For sma innertaer hos svin. Medl. Bl. for Norske Veterinaerforen, 19, 1967: 57-59.

BARONE, R.: Anatomie comparée des mammifères domestiques. Tomel, ostéologie. J. Tixier and Fils, Lyon, 1966.

BOL, B. K.: Pathologicko-anatomická pitva hospodárských zvirat (Preklad z ruského originálu). ČAZV, SZN, Praha, 1957.

CERVENÝ, ¿.: Ossa membri pelvini. In: Najbrt, R. et al.: Veterinary anatomy I. Státní zemědělské nakladatelství, Praha, 1980.

ELLENBERGER, W. - BAUM, H.: Handbuch der vergleichenden Anatomie der Haustiere, Stürtz,: H., Würzburg, 1943.

GEYER, H.: Morphologie und Wachstum der Schweineklaue. Habilitationsschrift, Vet.-Med. Fakultät Zürich, Zürich 1979; $111 \mathrm{p}$.

HOVORKA, J.: Hiavní faktory ovlivñujíci vyłazování plemenných kancú $v$ inseminaci. Veterinárstvi, 30, 1980a: 271-278.

HOVORKA, J.: Dysharmonie spárkú prasat - závažná, geneticky podmíněná porucha zdraví. Veterinářství, 30, 1980b: 348-350.

HUSER, R.: Zur Anatomie des Wildschweines. Diss., Zürich 1930

KAMAN, J.: Ossa membri thoracici. In: Najbrt, R. et al.: Veterinary Anatomy I. Státní zemědělské nakladatelství, Praha, 1980.

KAMAN, J. a kol.: K významu frekvence výskytu syndromu asymetrie špárkủ prasat ve velkochovech. Veterinárství, 36, 1986: 263-264.

KOCH, T.: Lehrbuch der Veterinäranatomie I, Bewegungsapparat. 3 th ed., VEB G. Fischer Verlag, Jena, 1976.

$\mathrm{KOCH}, \mathrm{T}$. - BERG, R.: Lehrbuch der Veterinäranatomie I. Bewegungsapparat. 4th ed., VEB G. Fischer Verlag, Jena, 1985.

KOLDA, J.: Srovnávací anatomie zvírat domácích I a II. Cást obecná, nauka o kostech a chrupavkách. Novina, Brno, 1936.

KRATOCHVIL, Z.: Discriminative characters on the acropodium of the domestic and wild pig (Sus scrofa f. domestica L., Sus scrofa L.). Acta vet., Brno, 42, 1973: 109-133.

LABIK, K. - PELIKÁN, J.: Disharmonie spárkú prasat - geneticky podmíněná zdravotní porucha. III. Přibylovy dny. Sborník přednášek. VSV, Košice, 1975.

LABIK, E. et al.: Patologickomorfologické nálezy u zvírat a jejich vztah $k$ dědičné podmíněnosti. Project P-11-329-051-02-06, VSV, Brno, 1975 .

LEMAN, A. D. et al.: Diseases of swine. 5 th ed., Iowa State Univ. Press, Iowa, USA, 1981.

LOJDA, L. - MRAZ, J.: Hereditary asymmetry of the development of the $3 \mathrm{rd}$ and 4 th toe in pigs causing locomotory disorders. Proc. 12th Genetic Days of Farm Animals, Nitra 1985: 304-305.

NICKEL, R. - SCHUMMER, A. - SEIFERLE, E.: Lehrbuch der Anatomie der Haustiere I. Bewegungsapparat. Paul Parey, Berlin-Hamburg, 1968.

NIELSEN, E.: Die Schleimbeutel und Sehnenscheiden der Gliedmassen des Schweines. Zbl. Vet. Med., 15, 1968: 562-571.

NORDBY, J. E.: Annual Report. Idaho Agricultural Experimental Station, 1936. In: Nordby, J. E.: Inequalities in the digits in swine. J. of Heredity, 30, 1939: 307-312.

NORDBY, J. E.: Inequalities in the digits in swine. J. of Heredity, 30, 1939: 307-312. 
ORSAG, A. a kol.: Veterinárna ortopédia a röntgenológia. Príroda Bratislava a SZN Praha, 1985.

PADELT, R.: Skelettmessungen am Schwein. Diss., Leipzig 1892.

POPESKO, P.: Atlas topografickej anatómie hospodárskych zvierat

III. Panva a končatiny. Slovenské vyd. pódohosp. lit., Bratislava, 1968.

SCHNEIDER, J. - ZINTZSCH, I.: Die Leitungsanästhesie an der

Extremitäten des Schweines. Zbl. Vet. Med., q 1962: 59-74.

SCHUMANN, H.: Erbliche Missbildungen der Extremitäten beim

Schwein. Tierärztliche Umschau, 12, 1957: 37-42.

SISSON, S.: The anatomy of the domestic animals. 3 th ed., W. B. Saunders Company, Philadelphia, London, 1947.

SKJERVOLD, H. et al.: Husdyrboka. Bøndenes Forlag, Oslo, 1966. SMITH and MITCHELL (1977) in: LEMAN, A. D. et al.: Diseases of swine. 5th ed., Iowa State Univ. Press, Iowa, USA, 1981. 